\title{
PENGARUH MEDIA SOSIAL, BRAND INFUENCER DAN KESADARAN MEREK TERHADAP MINAT BELI DI MARKETPLACE SHOPEE PADA SAAT PANDEMI COVID-19
}

\author{
Jonathan Herdioko; Carmel Verona Karisma \\ J1. Dr. Wahidin Sudirohusodo no. 5-25 Yogyakarta, Indonesia - 55224 \\ Telp. +62274563929, Fax: +62274513235 \\ email: jonathan@staff.ukdw.ac.id carmel.karisma@students.ukdw.ac.id
}

http://dx.doi.org/10.21460/jrmb.2021.162.395

\begin{abstract}
ABSTRAK
Penelitian ini bertujuan untuk mengetahui pengaruh sosial media, brand influencer, dan kesadaran merek terhadap minat beli di Marketplace Shopee pada saat pandemi Covid-19. Penelitian ini menggunakan pendekatan kuantitatif dengan metode survey. Jumlah sampel pada penelitian ini sebanyak 157 responden yang tersebar di tiga wilayah antara lain Indonesia Bagian Barat, Indonesia Bagian Tengah, dan Indonesia Bagian Timur, pengambilan sampel menggunakan teknik purposive sampling. Hasil dari penelitian ini menunjukkan bahwa secara parsial variabel media sosial tidak berpengaruh signifikan terhadap minat beli, variabel brand influencer berpengaruh signifikan terhadap minat beli, variabel kesadaran merek berpengaruh terhadap minat beli. Asal daerah sebagai pemoderasi variabel brand influencer dan kesadaran merek tidak berpengaruh signifikan terhadap minat beli. Pendapatan sebagai pemoderasi variabel brand influencer dan kesadaran merek tidak berpengaruh signifikan terhadap minat beli.
\end{abstract}

Kata Kunci: Media Sosial, Brand Influencer, Kesadaran Merek, Minat Beli

\begin{abstract}
This research is aimed to acknowledge the effects of social media, brand influencer, and brand awareness towards Shopee Marketplace buying intention during the Covid-19 pandemic. This research uses the quantitative approach by survey. There were 157 samples used and they came from the three regions of Indonesia. The purposive sampling method was used in this research. The results of this study indicate that partially, the social media variable has no significant effect on buying interest, the brand influencer variable has a significant effect on buying interest, the brand awareness variable has an effect on buying interest. Regional origin as a moderating variable for social media and brand awareness has no significant effect on buying interest. Income as a moderating variable for brand influencers and brand awareness has no significant effect on buying interest.
\end{abstract}

Keyword: Social Media, Brand Influencer, Brand Awareness, Buying Interest

\section{PENDAHULUAN}

E-commerce atau perdagangan melalui daring berkembang dengan cepat selama sepuluh tahun ini. Dapat dilihat bahwasanya dengan adanya e-commerce, paradigma perubahan pola aktivitas, promosi, dan perdagagan ekonomi mengalami perubahan yang mengubah pola manajemen dunia. Indonesia merasakan adanya perkembangan ini. Buktinya dengan banyaknya pengguna internet yang ada di Indonesia. Menurut Inet.detik.com (2021) jumlah pengguna internet di Indonesia mencapai 202,6 juta jiwa. Jumlahnya terus meningkat bila dibandingkan dengan tahun sebelumnya, yakni tahun 2020 
yang tercatat mencapai 189,7 juta jiwa. Data tersebut adalah survei yang dilaksanakan oleh APJII (Asosiasi Penyelenggara Jasa Internet Indonesia). Artikel ini telah tayang di Inet.detik.com dengan judul "Pengguna Internet Indonesia Tembus 202,6 Juta orang."

Menurut data yang dipublikasikan oleh APJII menunjukkan kalau ada 202,6 juta masyarakat Indonesia yang aktif memakai internet dengan penetrasi penggunaan internet sebayak +6,9 persen pertahun peningkatatannya. Awalnya fungsi internet digunakan untuk mencari berita. Namun seiring itu fungsinya bergeser untuk media sosial atau medsos.

Merujuk pada data di atas, terdapat 175,4 juta jiwa yang melakukan penggunaan internet pada berbagai platform. Selain itu, pengguna internet cenderung memakai internet perhari selama 7 jam 59 detik atau hampir 8 jam per hari. Pada 2020 APJII mempublikasikan bahwa ada 182 situs jual beli beroperasi di Indonesia. Berikut urutan sepuluh besar peringkat marketplace terlaris paling terkenal di Indonesia pada bulan Februari 2021 lalu adalah (1) Shopee, (2) Tokopedia, (3) Bukalapak, (4) Lazada, (5) Blibli, (6) Orami, (7) JD.ID, (8) Zalora, (9) Bhineka, dan (10) Matahari. Sedangkan, yang lain ada yang gulung tikar atau ada yang berakuisisi menjadi satu perusahaan.

Pandemi covid yang telah sudah lebih dari 1,5 tahun ini ternyata juga telah mengubah pola belanja masyarakat. Hal ini karena telah ada perubahan di dalam pola konsumsi yang tadinya kalau beli sesuatu harus datang ke tempat tersebut, kemudian adanya digitalisasi retail di mana kita bisa membeli barang dari telapak tangan kita tanpa harus beranjak dari tempat tidur. Kini dengan adanya era Pandemi Covid 19 dengan berbagai variannya telah membuat perubahan dalam pola konsumsi masyarakat secara umum untuk melakukan konsumsi pada marketplace yang ada di Indonesia.

\section{KAJIAN LITERATUR}

Media online (daring) adalah sebutan umum untuk sebuah bentuk media yang berbasis telekomunikasi dan multimedia (bacakomputer dan internet). Di dalamnya terdapat portal, website (situs web), radio-online, TVonline, pers online, email, dan lain-lain, dengan karakter tersediri sesuai dengan fasilitas yang memungkinkan pengguna memanfaatkannya. Online adalah istilah ketika kita sedang terkoneksi dunia maya atau internet, baik dengan akun social media kita, e-mail dan beragam jenis akun lain yang kita gunakan melalui internet. Sedangkan, yang dimaksud online di sini adalah marketplace. Definisi dari Marketplace ini sendiri adalah medium yang menjembatani penjual dan pembeli dalam dunia maya. Situs marketplace sebagai pihak ketiga (perantara) dalam transaksi online dengan memfasilitasi fitur penjualan dan pembayaran yang aman.

Beberapa ahli menyebutkan definisi pemasaran. Namun, pada intinya pengertian yang diungkapkan oleh para ahli mempunyai makna dan maksud yang sama. Menurut William J Stanton (2001),: "Pemasaran yaitu keseluruhan proses dari aktivitas usaha yang tujuannya merancang, memutuskan harga, menawarkan, mengiklankan, menyalurkan suatu produk yang bisa memberikan kepuasan akan kebutuhan pelanggan ataupun pembeli potensial" (Swastha dan Irawan, 2003:5). Sedangkan, berdasarkan Kamus Besar Bahasa Indonesia (KBBI) Th. 2008, "Pemasaran adalah sistem, prosedur, langkah, perilaku dalam mempromosikan produk secara meluas kepada masyarakat." Pemasaran yaitu sebuah peran dalam institusi serta prosedur membuat, menghubungkan, mempromosikan, menyediakan suatu nilai kepada konsumen, mitra, dan masyarakat.

\section{Media Sosial}

Antony Mayfield (2008) menyampaikan pendapatnya tentang social media yaitu Suatu saluran yang mana para pemakai dapat dengan gampang berkontribusi, bernagi, dan membentuk peran, terutama jejaring sosial, blog, forum virtual, termasuk dunia maya dengan karakter avatar. Definisi Media Sosial menurut Van Dijk (2013) (Fuchs dalam Nasrullah, 2015:11), yaitu dasar sebuah media atau paltform yang berfokus pada keberadaan pemakai yang menyediakan penggunanya dalam melakuakn kegiatan ataupun berkerjasama. Sebab itu, social media dipandang sebagai media perantara atau fasilitator online yang menegaskan inetraksi 
antar konsumen serta sebagai jalinan sosial untuk melakukan komunikasi.

Saat ini, social media mengajak siapapun yang berminat untuk berkontribusi secara bebas, bisa dengan memberikan informasi, pendapat atau komentar secara cepat dan tidak terbatas. Ciri social media yaitu pesan yang disampaikan tidak untuk satu orang melainkan ke masyarakat luas. Pesan yang dikirimkan bebas, tidak harus melewati portal penjaga. Selain itu, pesan yang diungkapan relatif lebih cepat dibandingkan dengan media lain, (koran, atau majalah yang cenderung membutuhkan waktu lebih lama) dan sang penerima pesan yang memutuskan waktu untuk berinteraksi.

\section{Brand Influencer}

Influencer yaitu seseorang yang diakui, diyakini, disukai oleh sebagian kelompok, segala sesuatu yang digunakan ataupun dikerjakan selalu disorot oleh public. Penggunaan influencer mampu membangun brand image yang baik dengan biaya yang relatif lebih rendah dibandingkan dengan memakai public figure seorang artis. Bahkan, terkadang tidak perlu seorang artis namun memiliki kemampuan berkomunikasi yang baik dan unik. Umumnya seorang influencer ditunjuk berdasar pada keahlian, keterampilan, kepopuleran (walaupun belum tentu selalu), maupun reputasi yang dimilikinya. Hal ini disampaikan dalam Hariyanti \& Wirapraja (2018).

Karakter angkatan milenial sangat akrab dengan teknologi internet, cenderung menggemari pendekatan daring berupa User Generated Content (UGC) yang diciptakan untuk perorangan. Generasi ini memakai social media untuk information gathering dan mengambil keputusan pembelian sutau barang dan jasa berdasar pada review (pendapat) atau ulasan dari orang lain yang sudah menggunakan/membeli barang atau jasa tersebut (disampaikan oleh Arini, Angga, \& Putra, 2019).

\section{Kesadaran Merek}

Pengertian brand awareness diungkapkan oleh Rossiter dan Percy (1996) yaitu "Kesanggupan konsumen untuk mengetahui dan menyebut brand tanpa golongannya secara spesifik untuk mengonsumsi". Soehadi (2005) menyatakan definisi kesadaran merek sebagai berikut "Menciptakan konsumen yang memahami jenis barang atau jasa di mana barang atau jasa tersebut sejajar. Dalam cakupan yang lebih besar, kesuksesan mewujudkan suatu kesadaran brand bergantung sejauh mana konsumen memahami brand tersebut dibuat atau diciptakan untuk memenuhi keperluannya"

Brand awareness di dalam Bahasa Indonesia diartikan dengan kesadaran merek. Brand awareness yaitu kesanggupan pelanggan untuk mengetahui secara spontan dan menyebutkan sebuah brand cukup dengan memandang objek, seperti logo, gambar, warna, dan lain-lain, yang mengilustrasikan personalitas sebuah merek. Keahlian pelanggan mengingat sebuah brand sangat penting untuk diciptakan dan dikaji karena merupakan apek utama yang memutuskan tindakan pelanggan ketika memutuskan pembelian suatu produk.

Kesadaran merek adalah suatu merek atau brand yang memiliki kesadaran tinggi akan membantu menyatukan gambaran yang baik pada merek itu sendiri karena kemampuan menjelajah merek yang tinggi didalam benak pelanggan. Kondisi sekarang mencetuskan bahwasanya suatu brand atau merek yang kesadarannya tinggi bisa melahirkan gambaran positif untuk barang atau jasa.

\section{Minat Pembeli}

Minat adalah bagian dari komponen kognitif yang berpengaruh terhadap tindakan serta minat bahkan sumber dorongan yang mampu menuntun individu untuk melaksanakan apa yang akan dilakukan. Minat pelanggan adalah unsur dari elemen sikap dan tindakan mengonsumsi.Minat beli menurut Kinnear dan Taylor (1995) adalah unsur dari elemen tindakan pelanggan dalam perilaku memakai, arah responden untuk berperilaku sebelum memutuskan untuk membeli betulbetul dilakukan.

Di sini, dijelaskan bahwa minat pembelian adalah keadaan individu sebelum mengambil langkah yang bisa dipakai sebagai pedoman untuk memperkirakan langkah atau tingkah laku tersebut. Minat pembelian sendiri adalah apapun yang berkaitan dengan rancangan pelanggan untuk membeli barang 
atau jasa tertentu baik jumlah yang diperlukan ataupun suatu waktu tertentu. Dengan kata lain minat beli merupakan afirmasi psikologis dari dalam diri pelanggan yang mempertimbangkan, membayangkan, memikirkan rancangan pembelian beberapa barang atau jasa dengan brand spesifik, seperti perspektif pola membeli serta tindakan konsumen tersebut.

Aspek dan indikator media sosial, brand infuencer dan kesadaran merek pada minat beli, karena minat membeli adalah suatu langkah yang dilakukan sebelum memutuskan untuk membeli. Kotler, Bowen, dan Makens menyampaikan bahwa dalam minat membeli pada prosedur pembelian (keputusan membeli) dipengaruhi oleh dua antara lain Unexpected situation atau keadaaan yang tak terduga dan Respect to Others atau perbuatan kepada orang lain.

\section{Perilaku Konsumen}

Definisi perilaku konsumen yaitu berbagai aktivitas faktual yang dilakukan seseorang dipengaruhi mental dan aspek lain yang mengarahkan mereka untuk menentukan dan memakai produk yang diinginkan (Kotler, 2005: 215). Perilaku konsumen yang dikemukakan oleh Mowen dan Minor (2002:6) adalah penelitian terkait komponen prosedur pertukaran dan pembelian yang menyangkut pendapatan, pemakaian, penyingkiran suatu produk, pengetahuan dan gagasan.

Perilaku konsumen yaitu kajian terkait perbuatan atau pola seseorang, kelompok, dan instansi untuk menentukan, memakai, menghilangkan, ataupun membeli sebuah produk untuk mencapai kepuasan atas keinginan dan kebutuhan konsumen. Pemahaman mengenai konsep dan juga kenyataan perilaku konsumen harus dimengerti dengan sepenuhnya. Selain itu, perilaku konsumen yaitu aktivitas yang dilaksanakan oleh seseorang, kalangan atau golongan yang berkaitan dengan proses minat untuk membeli di marketplace Shoppee pada masa pandemi.

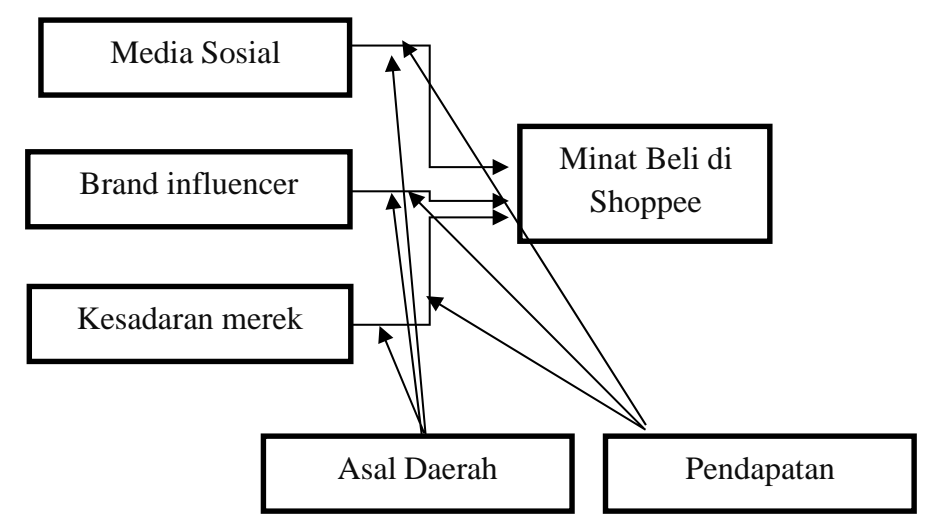

Gambar 1. Kerangka Konseptual Penelitian

\section{Hipotesis}

Hipotesis pada penelitian ini diperoleh dari tinjauan pustaka dan latar belakang masalah. Melalui uraian tersebut, muncullah hipotesis yaitu:

$\mathrm{H}_{1}$ : Media sosial berpengaruh secara parsial pada minat beli online shop Shopee pada saat pandemic Covid-19.

$\mathrm{H}_{2}$ : Brand influencer berpengaruh secara parsial pada minat beli online shop Shopee pada saat pandemic Covid-19.
$\mathrm{H}_{3}$ : Kesadaran merek berpengaruh secara parsial pada minat beli online shop Shopee pada saat pandemic Covid-19.

$\mathrm{H}_{4}$ : Asal daerah memoderasi minat beli online shop Shopee pada saat pandemic Covid-19.

$\mathrm{H}_{5}$ : Pendapatan memoderasi minat beli online shop Shopee pada saat pandemic Covid-19.

\section{METODA PENELITIAN}


Pemilihan responden di sini adalah responden yang tinggal di area Indonesia Bagian Barat, Indonesia Bagian Tengah, dan Indonesia Bagian Timur secara acak (purposive random sampling) sebanyak 157 orang. Adapun waktu studi ini adalah 4 bulan karena proses pembagian kuesioner serta wilayah jangkauan yang meliputi seluruh wilayah di Indonesia.Berikut variabel bebas yang digunakan sebagai definisi operasional pada studi ini antara lain Media Sosial, Brand Influencer, dan Kesadaran Merek.

\section{Tabel 1. Pengukuran Variabel Riset}

\begin{tabular}{|c|c|c|}
\hline Variabel & Definisi Operasional & Ukuran \\
\hline $\begin{array}{l}\text { Media } \\
\text { Sosial }\end{array}$ & $\begin{array}{l}\text { Media yang penggunanya mudah berpartisipasi, } \\
\text { berbagai dan menciptakan peran, khususnya } \\
\text { blog, jejaring sosial, wiki/ensiklopedia online, } \\
\text { forum-forum maya, termasuk dunia maya } \\
\text { (misalnya karakter 3D ataupun avatar). }\end{array}$ & $\begin{array}{l}\text { 1. Frekuensi munculnya } \\
\text { iklan } \\
\text { 2. Kemenarikan iklan } \\
\text { dalam media sosial } \\
\text { 3. Informasi iklan } \\
\text { 4. Isi/ kontent media } \\
\text { sosial } \\
\text { 5. Cara komunikasi } \\
\text { media sosial } \\
\text { 6. Foto di media sosial } \\
\text { 7. Video di social } \\
\text { media }\end{array}$ \\
\hline $\begin{array}{l}\text { Brand } \\
\text { Influencer }\end{array}$ & $\begin{array}{l}\text { Influencer yaitu seseorang yang diakui, diyakini, } \\
\text { disukai oleh sebagian kelompok, segala sesuatu } \\
\text { yang digunakan ataupun dikerjakan selalu } \\
\text { disorot oleh publik }\end{array}$ & $\begin{array}{l}\text { 1. Influencernya terkenal } \\
\text { 2. Komunikasi yang } \\
\text { menarik } \\
\text { 3. Reputasi brand } \\
\text { influencer } \\
\text { 4. Word of mouth } \\
\text { 5. Bujukan brand } \\
\text { influencer }\end{array}$ \\
\hline $\begin{array}{l}\text { Kesadaran } \\
\text { Merek }\end{array}$ & $\begin{array}{l}\text { Kemampuan pembeli untuk mengenal dan } \\
\text { menyebutkan merek tanpa kategorinya secara } \\
\text { detail untuk membeli sesuatu. }\end{array}$ & $\begin{array}{l}\text { 1. Merek sudah terkenal } \\
\text { 2. Produk yang dijual } \\
\text { merek berkualitas } \\
\text { 3. Layanan merek baik } \\
\text { 4. Warna } \\
\text { 5. Top of mind } \\
\text { 6. Persepsi harga pada } \\
\text { merek lebih murah }\end{array}$ \\
\hline
\end{tabular}

\section{HASIL PENELITIAN DAN PEMBAHASAN}

Bagian ini memuat informasi terkait profil responden, penilaian instrumen penelitian terkait kesahihan, keandalan, dan hasil penelitian mengenai variable yang digunakan. Obyek pada studi ini tentang Marketplace Shopee. Responden pada penelitian ini adalah responden yang tinggal pada area Indonesia Bagian Barat, Indonesia Bagian Tengah, dan Indonesia Bagian Timur 
yang didapatkan secara (purposive random sampling)

\section{Profil Responden}

Jenis kelamin

Tabel 2. Jenis Kelamin

\begin{tabular}{llll}
\hline No. & Gender & Jumlah & Presentase (\%) \\
\hline $\mathbf{1}$ & Laki-laki & 55 & $\mathbf{3 5}$ \\
$\mathbf{2}$ & Perempuan & 102 & $\mathbf{6 5}$ \\
Total & $\mathbf{1 5 7}$ & $\mathbf{1 0 0}$ \\
\multicolumn{2}{l}{ Sumber:Data yang sudah diolah, $(2021)}$.
\end{tabular}

Dari hasil pengumpulan data diperoleh responden laki laki sebanyak 55 (35.0\%), sedangkan untuk responden perempuan sebanyak 102 (65.0\%) Maka dapat disimpulkan mayoritas responden adalah perempuan

Usia

Tabel 3.Usia

\begin{tabular}{cccc}
\hline No. & Usia & Jumlah & Presentase (\%) \\
\hline $\mathbf{1}$ & $16-21$ tahun & 93 & $\mathbf{5 9 . 2}$ \\
$\mathbf{2}$ & $22-27$ tahun & 31 & $\mathbf{1 9 . 7}$ \\
$\mathbf{3}$ & $28-33$ tahun & 4 & $\mathbf{2 . 5}$ \\
$\mathbf{4}$ & $>34$ tahun & 29 & $\mathbf{1 8 . 5}$ \\
& Total & $\mathbf{1 5 7}$ & $\mathbf{1 0 0}$ \\
\hline
\end{tabular}

Sumber:Data yang sudah diolah, (2021).

Berdasar tabel disimpulkan jika frekuensi usia terbanyak dari responden adalah usia diantara 16-21 tahun, yaitu sebanyak 93 orang dengan presentase 59,2\%. Sedangkan frekuensi paling rendah berada pada kategori usia 28-33 tahun sebanyak 4 orang dengan presentase $2.5 \%$.

\section{Asal daerah}

Tabel 4. Asal Daerah

\begin{tabular}{cccc}
\cline { 2 - 4 } No. & Jenis Pekerjaan & Jumlah & Presentase (\%) \\
\cline { 2 - 4 } $\mathbf{1}$ & Indonesia Bagian Barat & 109 & $\mathbf{6 9 . 4}$ \\
$\mathbf{2}$ & Indonesia Bagian Tengah & 38 & $\mathbf{2 4 . 2}$ \\
$\mathbf{3}$ & Indonesia Bagian Timur & 10 & $\mathbf{6 . 4}$ \\
\hline & Total & $\mathbf{1 5 7}$ & $\mathbf{1 0 0}$ \\
\hline
\end{tabular}

Sumber:Data yang sudah diolah, (2021).

Berdasarkan tabel diatas dapat diketahui bahwa frekuensi daerah asal terbanyak dari responden adalah Indonesia Bagian Barat sebanyak 109 orang dengan presentase $69.4 \%$. Sedangkan frekuensi yang paling rendah adalah Indonesia Bagian Timur sebanyak 10 orang dengan presentase $6.4 \%$ 


\section{Pendidikan}

Tabel 5. Pendidikan

\begin{tabular}{cccc}
\hline No. & Jenis Pekerjaan & Jumlah & Presentase (\%) \\
\hline $\mathbf{1}$ & SMP & 93 & $\mathbf{5 9 . 2}$ \\
$\mathbf{2}$ & SMA/SMK & 55 & $\mathbf{3 5}$ \\
$\mathbf{3}$ & Sarjana & 9 & $\mathbf{5 . 7}$ \\
\hline & Total & $\mathbf{1 5 7}$ & $\mathbf{1 0 0}$
\end{tabular}

Sumber:Data yang sudah diolah, (2021).

Berdasarkan tabel di atas dapat SMP sebanyak 93 orang dengan presentase diketahui bahwa frekuensi pendidikan 59.2\%. Sedangkan frekuensi yang paling terbanyak dari responden adalah pada jenjang rendah adalah sarjana sebanyak.

\section{Pekerjaan}

Tabel 6. Pekerjaan

\begin{tabular}{cccc}
\hline No. & Jenis Pekerjaan & Jumlah & Presentase (\%) \\
\hline $\mathbf{1}$ & Mahasiswa & 99 & $\mathbf{6 3 . 1}$ \\
$\mathbf{2}$ & Wirausaha & 16 & $\mathbf{1 0 . 2}$ \\
$\mathbf{3}$ & ASN & 19 & $\mathbf{1 2 . 1}$ \\
$\mathbf{4}$ & Ibu Rumah Tangga & 4 & $\mathbf{2 . 5}$ \\
$\mathbf{5}$ & Lainnya & 19 & $\mathbf{1 2 . 1}$ \\
\hline & Total & $\mathbf{1 5 7}$ & $\mathbf{1 0 0}$
\end{tabular}

Sumber:Data yang sudah diolah, (2021).

Berdasarkan tabel di atas dapat diketahui bahwa frekuensi pekerjaan terbanyak dari responden adalah mahasiswa sebanyak 99 orang dengan presentase $63.1 \%$. Sedangkan frekuensi yang paling rendah adalah Ibu Rumah Tangga sebanyak 4 orang dengan presentase $2.5 \%$

\section{Pendapatan per Bulan}

Tabel 7. Pendapatan

\begin{tabular}{cccc}
\hline No & Pengeluaran per Bulan & Jumlah & Presentase (\%) \\
\hline $\mathbf{1}$ & Rp 1.000.000-Rp 2.000.000 & 101 & $\mathbf{6 4 . 3}$ \\
$\mathbf{2}$ & $>$ Rp 2.000.000-3.000.000 & 20 & $\mathbf{1 2 . 7}$ \\
$\mathbf{3}$ & $>$ Rp 3.000.000-4.000.000 & 12 & $\mathbf{7 . 6}$ \\
$\mathbf{4}$ & $>\operatorname{Rp~} 4.000 .000$ & 24 & $\mathbf{1 5 . 3}$ \\
\hline & Total & $\mathbf{1 5 7}$ & $\mathbf{1 0 0}$
\end{tabular}

Sumber:Data yang sudah diolah, (2021).

Berdasar pada tabel disimpulkan bahwa frekuensi responden dengan pendapatan per bulan terbanyak adalah pada rentang pendapatan Rp.1.000.000 - Rp. 2.000.000 dengan presentase $64.3 \%$ atau sejumlah 101 orang. Sedangkan frekuensi responden dengan 
pengeluaran per bulan terendah yang berkunjung ke gerai superindo adalah pada rentang pengeluaran sebesar >Rp.3.000.000 -

\section{Hasil Uji Validitas dan Reliabilitas}

\section{Uji Validitas}

Uji validitas pada studi ini memakai kuesioner yang telah dibagikan pada responden merupakan suatu alat ukur yang menunjukkan tingkat validitas/keaslian. Peneliti dapat mengetahui seberapa tepat suatu tes/uji dengan menjalankan fungsi pengukurannya, oleh karena itu dilakukan pengukurankevalidan butir kuesioner atau uji validitas. Ketentuan pengujian antara lain:

a. Pengujian mengggunakan taraf kesalahan $(\alpha)=5 \%$

b. Nilai rtabel didapatkan dari distribusi Tabel

$R$, total responden $(n)=30$.
Rp.4.000.000 sejumlah 12 orang dengan presentase $7.6 \%$.

c. $\mathrm{R}$ tabel bernilai 0,239 karena jumlah sampel $\mathrm{n}=30$ dikurangi $2(\mathrm{dk}=\mathrm{n}-2=28)$ dan taraf kesalahan yang digunakan adalah $5 \%$

d. Instrumen dikatakan valid atau sah bila nilai rhitung < rtabel.

Tabel 8 berikut hasil uji validitas menggunakan Product Moment dengan bantuan aplikasi SPSS 23. Berdasarkan tabel 8, hasil pengujian instrument penelitian pada tabel di atas menunjukkan nilai rhitung $>\mathrm{r}$ tabel, maka seluruh butir pernyataan dinyatakan valid sehingga dapat dibagikan. Berdasarkan tabel 9 hasil pengujian instrument penelitian pada tabel diatas menunjukkan nilai rhitung > rtabel, maka maka seluruh butir pernyataan dinyatakan valid sehingga dapat dibagikan.

Tabel 8. Hasil Uji Validitas Variabel Media Sosial

\begin{tabular}{cccc}
\hline Indikator & r hitung & r tabel & Keterangan \\
\hline Medsos1 & .506 & .239 & Valid \\
Medsos2 & .732 & .239 & Valid \\
Medsos3 & .769 & .239 & Valid \\
Medsos4 & .848 & .239 & Valid \\
\hline
\end{tabular}

Tabel 9. Hasil Uji Validitas Variabel Brand Influencer

\begin{tabular}{cccc}
\hline Indikator & $\mathbf{r}$ hitung & $\mathbf{r}$ tabel & Keterangan \\
\hline Bi1 & .905 & .239 & Valid \\
Bi2 & .912 & .239 & Valid \\
Bi3 & .941 & .239 & Valid \\
Bi4 & .910 & .239 & Valid \\
Bi5 & .949 & .239 & Valid \\
Bi6 & .846 & .239 & Valid \\
Bi7 & .903 & .239 & Valid
\end{tabular}


Tabel 10. Hasil Uji Validitas Variabel Kesadaran Merek

\begin{tabular}{cccc} 
Indikator & $\mathbf{r}$ hitung & $\mathbf{r}$ tabel & Keterangan \\
\hline Merk1 & .560 & .239 & Valid \\
Merk2 & .379 & .239 & Valid \\
Merk3 & .560 & .239 & Valid \\
Merk4 & .305 & .239 & Valid \\
\hline
\end{tabular}

Tabel 11. Hasil Uji Validitas Variabel Minat Beli

\begin{tabular}{cccc} 
Indikator & r hitung & r tabel & Keterangan \\
\hline Minat1 & .790 & .239 & Valid \\
Minat2 & .840 & .239 & Valid \\
Minat3 & .614 & .239 & Valid \\
\hline
\end{tabular}

Berdasarkan tabel 10, hasil pengujian instrument penelitian pada tabel di atas menunjukkan nilai rhitung > rtabel, maka seluruh butir pernyataan dinyatakan valid sehingga dapat dibagikan. Berdasarkantabel 11, hasil pengujian instrument penelitian pada tabel di atas menunjukkan nilai $r$ hitung lebih besar dari nilai rtabel, maka seluruh butir pernyataan pada penelitian dinyatakan valid dan pantas dibagikan.

\section{Uji Reliabilitas}

Uji reliabilitas memperlihatkan seberapa jauh hasil penilaian memakai item yang serupa akan menghasilkan infromasi yang serupa. Suatu alat ukur gejala bila tingkatannya bertambah tinggi maka alat ukur itu mampu diandalkan dan konstan. Ketentuan sebuah instrument dikatakan reliabel menurut Nunnally dalam Ghozali (2006:42) jika nilai Cronbach Alpha melebihi 0,6. Sedangkan, suatu variable dinyatakan tidak reliabel bila skor Cronbach Alpha $\leq 0,6$. Berdasar pada uji reliabilitas yang telah dilakukan diperoleh hasil yaitu nilai Cronbach's Alpha pada variabel media sosial 0.858 melebihi 0,6. Maka variable Media Sosial yang dipakai dinyatakan reliabel. Nilai Cronbach's Alpha pada variabel brand influencer $0.976>0.6$. Oleh karena itu, variabel Brand Influencer yang dipakai dinyatakan reliabel. Nilai Cronbach's Alpha pada variable brand awareness 0.66 yang melebihi 0.6. Oleh karena itu, variable Brand Awareness yang dipakai dinyatakan reliabel. Berdasar pada perhitungan uji reliabilitas ditunjukkan bahwasanya seluruh instrument dalam penelitian menghasilkan nilai Cronbach's Alpha 0.864 . Dengan demikian variabel Minat Beli yang dipakai dinyatakan reliabel.

Dari hasil pengolahan data statistik tanpa memasukan variabel moderasi diperoleh hasil sebagai berikut:

\section{Pengaruh Media Sosial Terhadap Minat beli}

Social Media tidak memberikan pengaruh signifikan pada minat pembelian konsumen. Hal ini dikarenakan media sosial bukanlah sebagai pertimbangan utama konsumen dalam menggunakan marketplace Shopee. Penelitian ini tidak sesuai dengan penelitian sebelumnya yang dilakukan oleh Rizki, Jeni, dan Nurhidayah (2021) bahwa media sosial berpengaruh signifikan terhadap minat pembelian.

\section{Pengaruh Brand Influencer Terhadap Minat Beli Konsumen}


Brand Influencer memberi pengaruh secara signifikan pada minat pembelian pelanggan. Hal tersebut didasari pada dunia pemasaran yang serba online pada saat ini, suatu perusahaan dituntut untuk selalu mengikuti trend agar tidak tertinggal oleh zaman. Dengan menggunakan Brand Influencer, dapat menguatkan reputasi merek perusahaan, meningkatkan keterlibatan audiens, sehingga dapat mempengaruhi minat konsumen untuk membeli. Hasil ini didukung oleh penelitian yang dilakukan oleh Arum dan Asmi (2020) yang menyatakan bahwa kredibilitas influencer mampu meningkatkan minat beli pada konsumen.

Tabel 12. Hasil Analisis Regresi Linier Berganda

\begin{tabular}{cccccc}
\hline \multirow{2}{*}{ Model } & \multicolumn{2}{l}{ Unstandardized Coefficients } & Standardized Coefficients & & Sig. \\
\cline { 2 - 3 } & $\mathrm{B}$ & Std. Error & Beta & & \\
\hline (Constant) & .699 & .763 & & .916 & .361 \\
Medsos & .086 & .047 & .108 & 1.844 & .067 \\
Bi & .221 & .021 & .594 & 10.31 & .000 \\
Merk & .234 & .046 & .270 & 5.050 & .000 \\
\hline
\end{tabular}

a. Dependent Variable: Minat

\section{Pengaruh Kesadaran Merek Terhadap Minat Beli Konsumen}

Brand awareness memberi pengaruh secara signifikan pada minat beli konsumen. Ketika Shopee memiliki merek yang dikenal luas oleh masyarakat dan membuat mereknya mudah diingat, memiliki logo atau simbol yang mudah dibedakan dengan merek lain, maka Shopee akan menjadi marketplace pilihan konsumen dan berpengaruh terhadap minat beli masyarakat. Studi ini didukung oleh penelitian yang dilakukan oleh Arnanda dan Andi (2021) serta Angela, Daru dan, Pratiwi (2021) bahwa kesadaran merek berpengaruh signifikan terhadap minat pembelian konsumen.

\section{Pengaruh Moderasi Asal Daerah terhadap Brand Influencer}

Setelah memasukkan variabel moderasi Asal Daerah untuk Brand Influencer diperoleh hasil sebagai berikut:

Tabel 13. Hasil Uji t dengan Asal Daerah sebagai Pemoderasi Brand Influencer

\begin{tabular}{|c|c|c|c|c|c|c|}
\hline & \multirow{2}{*}{ Model } & \multicolumn{2}{|c|}{$\begin{array}{l}\text { Unstandardized } \\
\text { Coefficients }\end{array}$} & \multirow{2}{*}{$\begin{array}{c}\text { Standardized } \\
\text { Coefficients } \\
\text { Beta }\end{array}$} & \multirow{2}{*}{$\mathrm{t}$} & \multirow{2}{*}{ Sig. } \\
\hline & & B & Std. Error & & & \\
\hline \multirow{4}{*}{1} & (Constant) & 1.097 & .734 & & 1.496 & 137 \\
\hline & $\mathrm{Bi}$ & .232 & .021 & .623 & 10.948 & .000 \\
\hline & Merk & .271 & .047 & .312 & 5.744 & .000 \\
\hline & M1 & .004 & .004 & .043 & .825 & .411 \\
\hline
\end{tabular}


Menurut data hitungan di atas ditemukan bahwa Asal Daerah tidak berpengaruh signifikan dalam memoderasi hubungan antara Brand Influencer dan minat beli. Dengan kata lain bahwa Asal daerah tidak mempengaruhi konsumen dalam memandang seorang Brand Influencer yang akhirnya tidak berpengaruh terhadap minat beli konsumen.

\section{Pengaruh Moderasi Asal Daerah terhadap Kesadaran Merek}

Setelah memasukkan variabel moderasi Asal Daerah untuk Kesadaran Merek diperoleh hasil sebagai berikut :

Tabel 14. Hasil Uji t dengan Asal Daerah sebagai Pemoderasi pada Kesadaran Merek

\begin{tabular}{cccccc}
\hline & \multicolumn{2}{c}{$\begin{array}{c}\text { Unstandardized } \\
\text { Coefficients }\end{array}$} & $\begin{array}{c}\text { Standardized } \\
\text { Coefficients }\end{array}$ & & \\
\cline { 2 - 3 } & $\mathrm{B}$ & Std. Error & Beta & & Sig. \\
\hline $1 \quad$ (Constant) & 1.221 & .736 & & 1.658 & .099 \\
$\mathrm{Bi}$ & .239 & .019 & .642 & 12.402 & .000 \\
Merk & .259 & .045 & .299 & 5.766 & .000 \\
M2 & .001 & .007 & .010 & .211 & .833
\end{tabular}

Hasil perhitungan dengan menggunakan SPSS menunjukkan Asal Daerah tidak berpengaruh signifikan dalam memoderasi interaksi antara kesadaran merek dan minat beli. Hal ini menunjukkan bahwa asal daerah tidak mempengaruhi kesadaranmerek terhadap minat beli konsumen. Asal daerah dari konsumen tidak berdampak pada kesadaran konsumen dan tidak berpengaruh terhadap naik turunnya minat beli konsumen.

\section{Pengaruh Moderasi Pendapatan terhadap Brand Influencer}

Setelah memasukkan variabel moderasi Pendapatan untuk Brand Influencer diperoleh hasil sebagai berikut:

Tabel 15. Hasil Uji t dengan Pendapatan sebagai Pemoderasi Brand Influencer

\begin{tabular}{|c|c|c|c|c|c|c|}
\hline & \multirow{2}{*}{ Model } & \multicolumn{2}{|c|}{$\begin{array}{l}\text { Unstandardized } \\
\text { Coefficients }\end{array}$} & \multirow{2}{*}{$\begin{array}{c}\begin{array}{c}\text { Standardized } \\
\text { Coefficients }\end{array} \\
\text { Beta }\end{array}$} & \multirow{2}{*}{$\mathrm{t}$} & \multirow{2}{*}{ Sig. } \\
\hline & & B & Std. Error & & & \\
\hline \multirow{4}{*}{1} & (Constant) & 1.319 & .713 & & 1.850 & .066 \\
\hline & $\mathrm{Bi}$ & .232 & .023 & .623 & 9.902 & .000 \\
\hline & Merk & .258 & .045 & .298 & 5.757 & .000 \\
\hline & M3 & .004 & .007 & .033 & .559 & .577 \\
\hline
\end{tabular}


Melalui tabel di atas ditemukan bahwa Pendapatan tidak berpengaruh signifikandalam memoderasi Brand Influencer dan minat beli. Dengan kata lain Pendapatan tidak mempengaruhi pandangan konsumen terhadap Brand Influencer yang pada akhirnya tidak memberi pengaruh pada minat pembelian pelanggan.

\section{Pengaruh Moderasi Pendapatan terhadap Kesadaran Merek}

Setelah memasukkan variabel moderasi Pendapatan untuk Kesadaran Merek memperoleh hasil seperti di bawah ini :

Tabel 16. Hasil Uji t dengan Pendapatan sebagai Pemoderasi Kesadaran Merek

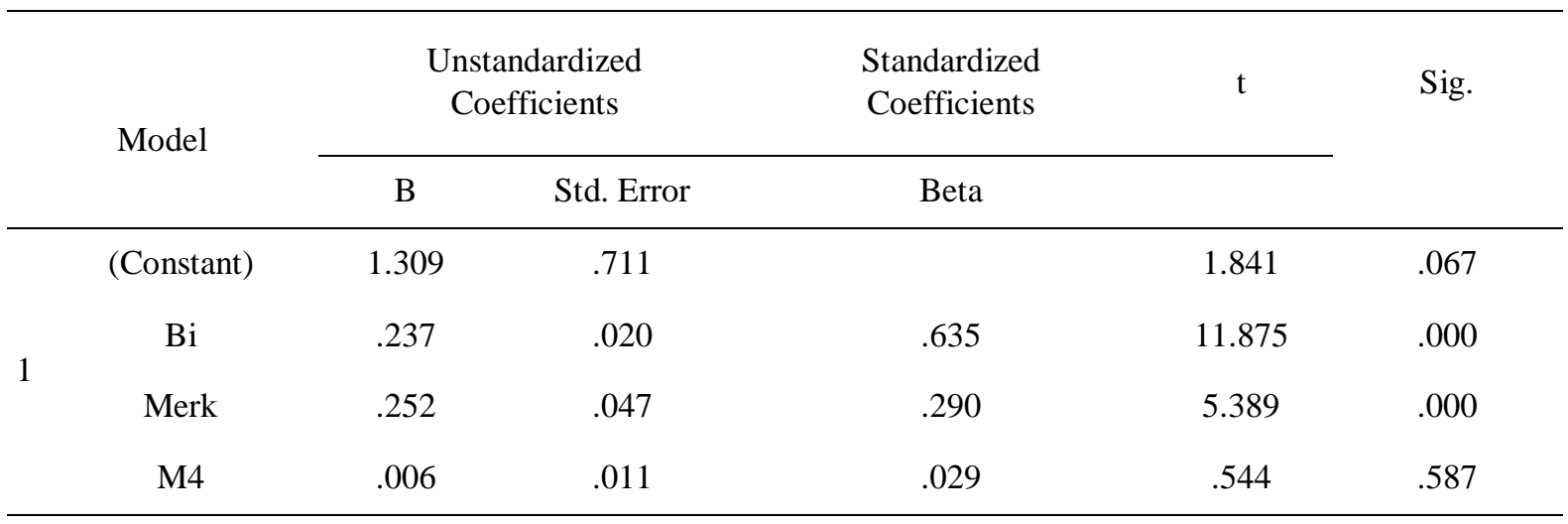

Melalui hasil perhitungan dengan menggunakan SPSS menunjukkan Pendapatan tidak berpengaruh signifikan dalam memoderasi interaksi antara brand awareness dengan minat beli. Perihal ini membuktikan bahwa Pendapatan tidak mempengaruhi brand awareness terhadap minat beli konsumen. Asal daerah dari konsumen tidak berdampak pada kesadaran konsumen dan tidak berpengaruh terhadap naik turunnya minat pembelian pelanggan.

\section{SIMPULAN DAN SARAN}

\section{Simpulan}

1. Pada model tanpa perubah pemoderasi, aspek media sosial tidak memberi pengaruh signifikan pada minat beli di marketplace Shopee saat pandemi covid-19. Sedangkan brand influencer, dan brand awareness berpengaruh signifikan pada minat beli di marketplace Shopee saat pandemi covid-19. Hal ini menunjukkan bahwa media sosial bukanlah menjadi pertimbangan utama konsusmen saat hendak menggunakan marketplace Shopee.

2. Pada aspek brand influencer, ketika seorang brand influencer mampu memperkenalkan marketplace Shopee dengan baik di benak konsumen, maka minat beli konsumen akan meningkat.

3. Pada aspek kesadaran merek, ketika konsumen telah mengenali merek marketplace Shopee, dan menemukan keunggulan dari Shopee, maka minat beli konsumen terhadap marketplace Shopee akan meningkat.

4. Pada model dengan pemoderasi asal daerah dalam kaitannya dengan brand influencer dan minat beli menunjukkan hasil yang $t$ idak signifikan. Hal ini mengindikasikan bahwa faktor brand influencer dan minat beli tidak dipengaruhi oleh daerah asal dari konsumen.

5. Pada model dengan pemoderasi asal daerah dalam kaitannya dengan kesadaran merek dan minat beli ternyata tidak signifikan. Maka diindikasikan bahwa asal daerah tidak memberi pengaruh pada kesadaran konsumen akan sebuah brand dan hal ini tidak berpengaruh terhadap hubungannya dengan minat beli konsumen.

6. Pada model dengan pemoderasi pendapatan dalam kaitannya dengan Brand Influencer dan minat beli menunjukkan hasil yang $\mathrm{t}$ idak signifikan. Hal ini mengindikasikan bahwa faktor Brand Influencer dan minat 
beli tidak dipengaruhi oleh Pendapatan konsumen.

7. Pada model dengan pemoderasi pendapatan dalam kaitannya dengan brand awareness serta minat beli tidak signifikan. Artinya bahwa pendapatan tidak mempengaruhi kesadaran konsumen akan brand dan hal ini tidak berpengaruh terhadap hubungannya dengan minat beli konsumen.

\section{Keterbatasan Penelitian}

1. Jumlah variabel terbatas sehingga hanya mampu mengkaji sebagian kecil variabel yang berpengaruh terhadap variabel minat beli pada marketplace Shopee pada saat pandemi covid-19.

2. Dalam pengisian kuesioner, mayoritas pengisi adalah dari kalangan tertentu sehingga bisa menjadi alasan media social

\section{DAFTAR REFERENSI}

Am'ndah, R. A., Susyanti, J., \& Nurhidayah. (2021). Pengaruh Media Sosial Instagram Dan Relationship Marketing Terhadap Minat Beli Konsumen Pada Era Industri 4.0 (Studi Kasus Pada Mahasiswa Fakultas Ekonomi Dan Bisnis Universitas Islam Malang). Jurnal Ilmiah Riset Manajemen, 14.

Antony, M. (2008). What is Social Media? London: iCrossing.

Asosiasi Penyelenggara Jasa Internet Indonesia. (2020). Laporan Survei Internet APJII 2019 - 2020 [Q2]. Retrieved Mei 10, 2021, from apjii: https://apjii.or.id/survei

Hanindharputri, M. A., \& Putra. (2019). Peran Influencer dalam Strategi Meningkatkan Promosi dari Suatu Brand. Seminar Nasional Sandyakala.

Hariyanti, N., \& Wirapraja, A. (2018). Pengaruh Influencer Marketing sebagai Strategi Pemasaran Digital Era Modern (Sebuah Studi Literatur). Jurnal Eksekutif, 133-146.

Haryanto, A. T. (2021, Februari Selasa). Pengguna Internet Indonesia Tembus 202,6 Juta. Retrieved from DetikInet: https://inet.detik.com/cyberlife/d5407210/pengguna-internet-indonesiatembus-2026-juta tidak menjadi pengaruh terhadap mint beli Shopee.

\section{Saran untuk penelitian yang akan datang}

1. Mengganti variabel lain yang merupakan faktor yang mempengaruhi minat beli pada marketplace Shopee pada saat pandemi covid-19 (kualitas pelayanan, brand image, promosi dan brand ambassador).

2. Menyebar penelitian pada kelompok usia tertentu untuk dapat melihat alasan minat atau keputusan akhir dalam pembelian di Shopee bisa berbeda dari penelitian ini.

3. Mengulang penelitian yang sama di saat pandemic berakhir yang memungkinkan akan mendapatkan hasil yang berbeda

KBBI. (2008). Kamus Besar Bahasa Indonesia. Jakarta: Balai Pustaka.

Kinnear, T. C., \& Taylor, J. R. (1995). Riset Pemasaran, Edisi Tiga. Jakarta: Erlangga.

Kotler, P. (2005). Manajemen Pemasaran. Jilid 1 dan 2. Jakarta: PT Indeks Kelompok Gramedia.

Mowen, \& Minor, M. (2002). Perilaku Konsumen. Jakarta: Erlangga.

Nasrullah, R. (2015). Media Sosial Perspektif Komunikasi, Budaya dan Sosioteknologi. Bandung: Simbiosa Rekatama Media.

Purbohastuti, A. W., \& Hidayah, A. A. (2020). Meningkatkan Minat Beli Produk Shopee Melalui Celebrity Endorser. Jurnal Bisnis Terapan, 45.

Rossiter, \& Percy. (1996). Advertising Communication and Promotion Management. 2nd Edition. Singapore: Mc Grow-Hill.

Setiawan, A. M., Purnomo, D., \& Harnita, P. C. (2021). Analisis Pengaruh Promosi ECommerce Di Youtube Terhadap Brand Awareness dan Dampaknya Terhadap Minat Beli (Survei Eksplanatif Pada Shopee Versi 10.10 Brands Festival Di Kalangan Mahasiswa Di Kota Salatiga). Jurnal Cakrawala, 70-75. 
Soehadi. (2005). Effective Branding. Bandung: PT Mizan Pustaka.

Stanton, W. J. (2001). Prinsip-prinsip Pemasaran, Jilid Ketujuh. Jakarta: Erlangga.

Swastha, B., \& Irawan. (2003). Manajemen Pemasaran Modern. Yogyakarta: Liberty.

Thamrin. (2003). Manajemen Produksi dan Industri Kecil. Jakarta: Pusat Penerbitan Universitas Terbuka.

Wasli, A. (2021, Maret 18). Pengunjung Marketplace Tertinggi Februari 2021

Pada Iprice. Retrieved from
Teknologi:

https://teknologi.id/technology/pengun jung-marketplace-tertinggi-februari2021-pada-iprice

Wijayanto, A., \& Nikmatulloh, A. A. (2021). Pengaruh Kesadaran Merek, Kepercayaan, Dan Harga Terhadap Minat Beli Online Pada Marketplace Bukalapak(Studi pada Pengguna Bukalapak di Kota Semarang). Jurnal Ilmu Administrasi Bisnis, 846-847.

\section{Copyrights}

Copyright for this article is retained by the author(s), with first publication rights granted to the journal.

This is an open-access article distributed under the terms and conditions of the Creative Commons Attribution license (http://creativecommons.org/licenses/by/4.0/). 